\title{
Tingkat Kemampuan Berfikir Reflektif Siswa Sekolah Dasar Kelas Tinggi
}

\author{
Novy Trisnani \\ IKIP PGRI Wates, Yogyakarta, Indonesia \\ novy_trisnani@yahoo.com
}

\begin{abstract}
The ability to think reflective is an important ability to be developed in the mathematics learning process because it contains critical thinking skills and creative thinking skills. The purpose of this study was to assess the level of reflective thinking skills of elementary school students in high grades. This type of research is library research. The research data was obtained through a review of literature sources, including literature from print and online research journals, proceedings, reference books according to topics, modules, and other relevant sources. The ability to think reflective of elementary school students in high grades includes, first mentioning things in basic knowledge what is asked in the questions, what is known, mentioning the relationship between what is asked and what is known, and so on. Second, displaying problem-solving ideas designed according to known knowledge. Third, look back at the problem solving that has been made in order, including correcting and explaining if there is an error from the answer, and making conclusions correctly.
\end{abstract}

Keywords: Reflective thinking ability, Elementary school, High grades

Abstrak: Kemampuan berpikir reflektif merupakan kemampuan yang penting untuk dikembangkan dalam proses pembelajaran matematika karena di dalamnya memuat kemampuan berpikir kritis dan kemampuan berpikir kreatif. Tujuan dari penelitian ini adalah mengkaji tingkat kemampuan berpikir reflektif siswa sekolah dasar pada pembelajaran matematikadi kelas tinggi. Jenis penelitian ini adalah penelitian pustaka (library research). Data penelitian diperoleh melalui kajian dari sumber pustaka antara lain literatur yang berasal dari jurnal penelitian cetak dan online, prosiding seminar, buku referensi sesuai topik, modul, serta sumber lain yang relevan. Kemampuan berpikir reflektif siswa sekolah dasar pada pembelajaran matematika di kelas tinggi 
meliputi, pertama menyebutkan hal-hal dalam pengetahuan dasar apa saja yang ditanyakan dalam soal, apa yang diketahui, menyebutkan hubungan antara yang ditanya dengan yang diketahui, dan lain-lain. Kedua, menampilkan ide pemecahan masalah yang dirancang sesuai pengetahuan yang telah diketahui. Ketiga, melihat kembali penyelesaian masalah yang telah dibuat sesuai dengan urutan, termasuk di dalamnya adalah memperbaiki dan menjelaskan jika terjadi kesalahan dari jawaban, dan membuat kesimpulan dengan benar.

Kata Kunci: Kemampuan berpikir reflektif, Matematika, Kelas tinggi

\section{PENDAHULUAN}

Mata pelajaran matematika merupakan subjek penting dalam pembelajaran di persekolahan, terutama sekolah dasar. Pembelajaran matematika di sekolah dasar dilakukan melalui suatu proses pemberian pengalaman belajar berupa serangkaian kegiatan terencana dengan tujuan agar siswa dapat mencapai kompetensi tentang materi matematika yang dipelajari sesuai dengan tujuan diadakannya pembelajaran. Menurut Gravemeijer ${ }^{1}$, sudah sejak lama, tujuan pendidik melaksanakan pembelajaran matematika adalah agar siswa mempunyai keterampilan seperti berpikir kritis, problem posing, pemecahan masalah, kemampuan berkolaborasi, dan kemampuan berkomunikasi. Untuk mencapai kemampuan tersebut, bekal utama adalah siswa harus dilatih tentang cara berpikir dan menalar untuk menarik kesimpulan dari suatu penyelesaian permasalahan. Contoh kegiatan pembelajaran matematika sekolah dasar yang memerlukan keterampilan berpikir dan bernalar antara lain dalam kegiatan menyelidiki, menunjukkan kesamaan dan perbedaan, melakukan eksperimen, mengeksplorasi, serta melihat konsistensi dan inkonsistensi suatu permasalahan untuk menemukan solusi.

Tujuan mata pelajaran matematika diberikan kepada semua peserta didik, menurut Permen Nomor 22 Tahun 2006 adalah untuk membekali siswa dengan kemampuan berpikir logis, analitis, sistematis, kritis, dan kreatif, serta kemampuan bekerja sama. Berdasarkan Permen tersebut, maka peningkatan pengetahuna siswa terutama dalam keterampilan berpikir tingkat tinggi menjadi salah satu dari banyak prioritas dalam tujuan pelaksanaan pembelajaran matematika. Kemampuan berpikir reflektif merupakan salah satu aspek kemampuan berpikir tingkat tinggi (HOTS) yang di dalamnya memuat kemampuan berpikir kritis dan kemampuan berpikir kreatif. Kemampuan ini penting untuk dikembangkan bagi para siswa terutama siswa sekolah dasar dalam rangka langkah awal penyesuaian

1 Gravemeijer, K., Stephan, M., Julie, C. et al. (2017). What Mathematics Education May Prepare Students for the Society of the Future?. Int J of Sci and Math Educ. V 15, 105-123 (2017). https://doi.org/10.1007/s10763-017-9814-6. 
memasuki era globalisasi, dimana di era globalisasi tingkat kerumitan masalah di semua aspek modern hidup semakin tinggi.

Berpikir reflektif merupakan suatu proses menghubungkan pengetahuan yang telah dimiliki sebelumnya dan yang sedang dipelajari pada

aspek menganalisa masalah, mengevaluasi, menyimpulkan, dan memutuskan penyelesaian/solusi terbaik terhadap permasalahan yang diberikan ${ }^{2}$.Dalam penelitiannya Fuady juga menyatakan bahwa berpikir reflektif penting untuk dimiliki guru dan siswa, namun fakta yang ada menunjukkan bahwa berpikir reflektif kurang mendapat perhatian yang serius dari guru, guru menilai solusi suatu permasalahan hanya dari jawaban akhir yang diberikan oleh siswa tanpa memperhatikan bagaimana solusi/jawaban tersebut didapatkan. Pernyataan tersebut diperkuat juga oleh penelitian Ariestyan ${ }^{3}$ yang menyatakan bahwa kemampuan berpikir reflektif selama ini belum menjadi bagian dari tujuan pembelajaran matematika, masih jarang diperkenalkan guru, dan jarang dikembangkan pada siswa. Jika kondisi tersebut terus berlanjut maka akan mengakibatkan rendahnya kemampuan berpikir reflektif matematika siswa.

Kemampuan berpikir siswa sekolah dasar tentulah berbeda dengan kemampuan berpikir matematika tingkat persekolahan lainnya. Hal ini dikarenakan karakteristik siswa sekolah dasar yang tingkat berpikirnya masih dalam tahap operasional-konkret dan formal-operasional. Untuk dapat mengembangkan kemampuan berpikir reflektif, konsekuensi proses pembelajaran yang harus dilakukan adalah perlunya perencanaan pembelajaraan yang dapat menumbuh kembangkan kemampuan berpikir reflektif siswa. Dimensi kognitif yang berkaitan dengan materi pembelajaran hendaknya dirancang untuk dikembangkan di kelas secara hierarkis dan kronologis, agar kompetensi yang diperoleh siswa nantinya tidak hanya sebatas mengetahui dan menguasai materi namun juga mampu menerapkan dan mengimplementasikan hasil pemecahan untuk menyelesaikan masalah yang muncul di lain waktu.

Berkenaan dengan uraian di atas, serta bahwa jarangnya kemampuan berpikir reflektif diajarkan dan dikembangkan dalam pembelajaran matematika telah menyebabkan dangkalnya pengetahuan siswa dan rendahnya kemampuan berpikir reflektif, maka penting bagi guru untuk mengembangkan atau merancang rencana pembelajaran yang dapat melatih meningkatkan kemampuan berpikir reflektif. Untuk itu pendidik selayaknya mengetahui tentang sejauh mana kemampuan siswa yang di didiknya. Oleh karena itu dalam penelitian ini akan dikaji tentang tingkat kemampuan berpikir reflektif pada siswa sekolah dasar, dan hasilnya diharapkan dapat menjadi acuan bagi guru dan pembaca dalam merancang dan mengembangkan proses pembelajaran yang dapat mendorong

2 Fuady, A. (2016). Berfikir Reflektif Dalam Pembelajaran Matematika. Jurnal Ilmiah Pendidikan Matematika Volume 1 Nomor 2. Hal. 104-112.

3 Ariestyan, Y., Sunardi, \& Kurniati, D. (2016). Proses Berpikir Reflektif Siswa Dalam Menyelesaikan Soal Matematika Materi Sistem Persamaan Linear Dua Variabel. Jurnal Kadikma, Vol.7,No.1, hal 94-104. 
meningkatnya kemampuan berpikir reflektif siswa, terutama siswa sekolah dasar kelas tinggi.

Berkenaan dengan uraian di atas, serta bahwa jarangnya kemampuan berpikir reflektif diajarkan dan dikembangkan dalam pembelajaran matematika telah menyebabkan dangkalnya pengetahuan siswa dan rendahnya kemampuan berpikir reflektif, maka penting bagi guru untuk mengembangkan atau merancang rencana pembelajaran yang dapat melatih meningkatkan kemampuan berpikir reflektif. Untuk itu pendidik selayaknya mengetahui tentang sejauh mana kemampuan siswa yang di didiknya. Oleh karena itu dalam penelitian ini akan dikaji tentang tingkat kemampuan berpikir reflektif pada siswa sekolah dasar, dan hasilnya diharapkan dapat menjadi acuan bagi guru dan pembaca dalam merancang dan mengembangkan proses pembelajaran yang dapat mendorong meningkatnya kemampuan berpikir reflektif siswa, terutama siswa sekolah dasar kelas tinggi.

\section{METODE}

Metode penelitian yang dipakai dalam penelitian ini adalah penelitian riset pustaka/ library research. Perolehan data dalam penelitian ini diambil dari beberapa sumber referensi pendukung sebagai acuan dalam melakukan penelitian. Buku teks digunakan sebagai dasar teori dalam mengkaji pustaka dan hasil perolehan data. Referensi jurnal dan prosiding dipergunakan untuk mengkaji dan mempelajari penelitian-penelitian terkini yang terkait dengan penelitian. Sumber pustaka antara lain literatur yang berasal dari jurnal penelitian cetak dan online, prosiding seminar, buku referensi sesuai topik, modul, serta sumber lain yang relevan dengan bahan kajian dalam penelitian.

\section{PEMBAHASAN}

\section{Siswa Sekolah Dasar Kelas Tinggi}

Siswa sekolah dasar kelas tinggi adalah siswa yang beumur 10 sampai 13 tahun. Pada usia tersebut dapat diklasifikasikan bahwa siswa berada pada tahap perkembangan kognitif tahap konkret operasional dan formal-operational. Dalam tahap periode konkret-operasional ini siswa memperoleh tambahan kemampuan satuan langkah berpikir. Kemampuan tersebut bermanfaat bagi siswa terutama ketika siswa perlu mengkoordinasikan pemikiran dan idenya dengan kejadian/bentuk permasalahan (soal) tertentu ke dalam cara berpikirnya sendiri.

Tahap konkret-operasional menggambarkan langkah penting perkembangan kognitif anak. Menurut Piaget, karakteristik pemikiran dalam tahap ini ditandai dengan kemampuan operasi logis, seperti konservasi (pengekalan), reversibilitas atau klasifikasi, yang memungkinkan penalaran logis 4 .

4 Börnert-Ringleb, M. \& Wilbert, J. (2018). The Association of Strategy Use and Concrete-Operational Thinking in Primary School. Front. Educ. 3:38. doi: 10.3389/feduc.2018.00038. 
Menurut Shaffer, et $a l^{5}$, prinsip konservasi anak-anak pada tahap ini telah berkembang seperti setengah liter air memiliki jumlah yang sama walaupun dimasukkan baik itu gelas yang lebih tinggi atau lebih luas. Dalam hal klasifikasi, anak-anak pada tahap ini telah dapat mengklasifikasikan objek menjadi berbagai jenis seperti bentuk, nilai, dan ukuran, selain itu mereka telah dapat mempertimbangkan asosiasi mereka ${ }^{6}$.

Berdasarkan beberapa uraian di atas maka kemampuan kognitif siswa dalam melakukan operasi matematika pada tahap konkret-operasional meliputi: 1) conservation/pengekalan, yaitu kemampuan anak dalam memahami aspek-aspek materi penambahan atau penumpukkan, 2) addition of classes/penambahan berdasarkan golongan benda atau kesamaan sifat yang dimiliki suatu benda, 3) multiplication of classes/pelipatgandaan berdasarkan golongan benda atau kesamaa sifat yang dimiliki suatu benda serta membuang atau memisahkan benda yang tidak mempunyai kesamaa sifat/ciri. Dengan demikian pada tahap konkret operasional ini siswa sekolah dasar kelas tinggi telah mulai mempunyai kemampuan mengkoordinasikan pendapat orang lain dengan pandangan/pendapatnya sendiri, dan memiliki perspektif positif bahwa pandangannya/pendapatnya merupakan salah satu dari sekian banyak pandangan yang muncul. Keterbatasan pemikiran siswa pada tahap konkret-opersional adalah siswa pada usia ini baru mampu berpikir secara sistematis apabila berhadapan dengan benda-benda dan peristiwa-peristiwa yang bersifat konkret.

Selain tahap konkret-operasional siswa sekolah dasar kelas tinggi juga berada pada tahap kognitif formal-operasional. Menurut Piaget, pada formaloperasional pemikiran dan pemahaman anak telah berkembang secara signifikan ${ }^{7}$, dan telah mempunyai kemampuan berpikir secara logis serta mampu menyelesaian permasalahan matematika yang bersifat abstrak ${ }^{8}$. Kemajuan kemampuan kognitif dialami siswa pada tahap ini yaitu munculnya kemampuan mereka dalam mengatasi keterbatasan pemikiran pada tahap operasinal-konkret. Perkembangan kognitif siswa sekolah dasar kelas tinggi atau siswa pada tahap formal-operasional yaitu siswa sudah memiliki kemampuan mengkoordinasikan kapasitas penggunaan hipotesis dan penggunaan prinsip-prinsip abstrak, baik itu secara berurutan maupun bersama-sama. Dengan dimilikinya kemampuan mengkoordinasikan kapasitas penggunaan hipotesis, siswa pada tahap ini dalam memecahkan suatu permasalahan telah mampu menggunakan anggapan dasar yang relevan dengan pengalaman atau ingatan dari dalam dirinya. Sementara itu dengan dimilikinya kapasitas menggunakan prinsip-prinsip abstrak, siswa sekolah

5 Babakr, Z. H., Mohamedamin, P., \& Kakamad, K. (2019). Piaget's Cognitive Developmental Theory: Critical Review. In: Education Quarterly Reviews, Vol 2 No.3, 517-524.

6 King, L. A. (2011). The Science of Psychology: An Appreciative View. New York: McGraw-Hill.

7 Babakr, Z. H., Mohamedamin, P., \& Kakamad, K. (2019). Piaget's Cognitive Developmental Theory: Critical Review. In: Education Quarterly Reviews, Vol 2 No.3, 517-524.

8 Pastorino, E.E., \& Doyle-Portillo, S. M. (2013). What is Psychology? Essentials. Belmont, USA: Wadsworth, Cengage Learning. 
dasar kelas tinggi telah mampu mempelajari materi-materi pelajaran yang bersifat abstrak dengan lebih luas dan lebih mendalam.

\section{Berpikir Reflektif}

Berpikir merupakan suatu usaha sejauh kemampuan yang ada pada diri seseorang, dalam hal ini adalah siswa untuk menyelesaikan suatu permasalahan. Berpikir dapat ditandai dengan adanya suatu aktivitas mental atau aktivitas kognitif. Aktivitas ini berupa usaha mengolah atau memanipulasi informasi dari lingkungan dan ingatan yang ada di otak siswa, khususnya yang ada dalam long term memory mereka. Sobur', menyatakan bahwa berpikir merupakan aktivitas mental yang melibatkan otak dalam upaya untuk memahami sesuatu yang dialami atau menemukan solusi dari permasalahan yang dihadapi. Penyelesaian masalah dari proses berpikir diperoleh dari usaha siswa mengkaitkan berbagai pengetahuan yang telah dimilikinya dengan kemungkinan-kemungkinan yang ada sehingga mendapatkan solusi dari permasalahan yang diberikan. Dalam penelitian ini, pengertian berpikir yaitu suatu proses kognitif yang terjadi antara stimulus yang diberikan dan respon jawaban dalam rangka mendapatkan solusi pemecahan masalah dari persoalan yang dihadapi/diberikan.

Berpikir reflektif merupakan salah satu tahapan dari berpikir higher order thinking skills (HOTS) yang penting untuk mendapat perhatian karena kemampuan berpikir reflektif memiliki hubungan yang sangat erat dengan kemampuan berpikir metakognitif. Berpikir metakognitif merupakan proses berpikir dengan cara memeriksa dan membedakan perilaku berpikir. Selain itu, untuk berpikir reflektif dan berpikir metakognitif, seseorang perlu membangun koneksi dengan pengalaman yang pernah didapatkan untuk mengajukan pertanyaan tentang apa yang sedang dipelajari dan meyakinkan dii dalam proses pembelajaran ${ }^{10}$. Menurut Suharna ${ }^{11}$, berpikir reflektif adalah aktivitas berpikir yang mengaitkan informasi masalah yang dihadapi dengan pengalaman yang dimiliki ketika menyelesaikan masalah. Kemampuan berpikir reflektif adalah kemampuan siswa dalam memahami proses berpikir logis dengan cara memeriksa atau mengingat kembali pengetahuan yang pernah diperoleh dan dapat membantunya memperoleh solusi pemecahan masalah dari permasalahan yang dihadapi ${ }^{12}$. Karakteristik berpikir reflektif antara lain: 1) berpikir reflektif sebagai suatu analisis retrospektif atau

9 Lambertus, et al. (2019). Senior High School Students. Different Cognitive Styles and Their Thinking Processes in Solving Mathematical Problems with Scaffolding. International Journal of Innovation, Creativity and Change (IJICC). Volume 10, Issue 6, 2019. Pg 163-174)

10 Sunbul, A.M. \& Kurnaz, A. (2016). Reflective Thinking and Teaching Reflective Thinkin. International Journal on New Trends in Education and Their Implications-IJONTE. Pg. 167-173

11 Suharna, H. (2012). Berpikir Reflektif (Reflective Thinking) Siswa SD Berkemampuan Matematika Tinggi Dalam Pemahaman Masalah Pecahan. Seminar nasional matematika dan pendidikan matematika. (pp. 377-386).

12 Nuriadin, I., et al. (2015). Enhancing Of Students' Mathematical Reflective Thinking Ability Through Knowledge Sharing Learning Strategy In Senior High School. International Journal of Education and Research Vol. 3 No. 9 September 2015. 
mengingat kembali, 2) berpikir reflektif sebagai proses pemecahan masalah, 3) berpikir reflektif sebagai refleksi kritis pada diri, dan 4) berpikir reflektif sebagai bentuk refleksi pada keyakinan yang dimiliki ${ }^{13}$.

Banyak ahli telah mengungkap tentang pentingnya berpikir reflektif dalam proses belajar ${ }^{14,15,16}$. Pembelajaran reflektif merupakan proses yang berkaitan dengan kegiatan siswa untuk mengekplorasi pemahaman mereka tentang tindakan, proses, dan pengalaman mereka, serta dampaknya pada diri mereka sendiri dan orang lain ${ }^{17}$. Berpikir reflektif dapat membuat siswa melakukan pemikiran secara aktif, terus-menerus, dan penuh kehati-hatian untuk mengambil tindakan penyelesaian dan penyimpulan berdasarkan hasil pemikiran rational mereka. Dari beberapa pendapat ahli diatas maka dapat disimpulkan bahwa berpikir reflektif merupakan suatu kegiatan aktif yang didalamnya dibutuhkan upaya untuk menjelaskan berbagai hal, dan mencoba untuk menghubungkan ideide atau pemikiran untuk mendapatkan makna yang mendalam dalam rangka menerapkan strategi yang paling tepat dalam menyelesaiakan masalah yang dihadapi.

\section{Kemampuan Berpikir Reflektif}

Untuk melihat sejauh mana tingkat kemampuan berpikir reflektif pada siswa sekolah dasar kelas tinggi maka peneliti akan menggunakan kajian-kajian atau penelitian-penelitian terbaru tentang kemampuan berpikir reflektif yang pernah dilakukan. Weast mengkategorikan keterampilan berpikir reflektif meliputi keterampilan mengidentifikasi kesimpulan, mengidentifikasi alasan dan bukti, mengidentifikasi bahasa yang ambigu, mengidentifikasi asumsi dan konflik nilai, mengidentifikasi asumsi deskriptif, mengevaluasi penalaran logis, mengidentifikasi informasi yang dihilangkan, dan mengartikulasikan nilai-nilai diri sendiri dengan cara yang bijaksana dan pemikiran terbuka ${ }^{18}$. Beberapa penelitian lain yang mendasarkan pada pandangan tahapan berpikir reflektif adalah Mezirow

13 Choy, S. C. \& Oo, P.S. (2012). Reflective Thinking and Teaching Practices: A Precursor for Corporating Critical Thinking Into The Classroom. International Journal of Instruction v5 n1 p167-182.

14 Deringöl, Y. (2019). The relationship between reflective thinking skills and academic achievement in mathematics in fourth-grade primary school students. International Online Journal of Education and Teaching (IOJET) V 6(3). 613-622.

15 Tican, C. \& Taspinar, M. (2015). The Effects of Reflective Thinking-based Teaching Activities on Pre-service Teachers' Reflective Thinking Skills, Critical Thinking Skills, Democratic Attitudes, and Academic Achievement. The Anthropologist Journal, 20(1,2): 111-120.

16 Gurol, A. (2011). Determining The reflective thinking skills Of Pre-serviceTeachers in Learning and Teaching Process. Energy Education Science and Technology Part B: Social and Educational Studies, Volume (issue) 3(3): 387-402.

17 Mann, K., Gordon, J., \& Macleod, A. (2009). Reflection and Reflective Practice in Health Professions Education: A Systematic Review. Advance in Health Science Education, 14, 595621. http://dx.doi.org/10.1007/s10459-007-9090-2.

18 Weast, D. (1996). Alternative Teaching Strategies: The Case for Critical Thinking. Teaching Sociology,24, 189-194 
yang mengklasifikasikan berpikir reflektif ke dalam empat tahap berbeda, antara lain tindakan kebiasaan (babitual action), pemahaman (understanding), refleksi (reflection), dan refleksi kritis (critical reflection) 19,20,21,22.

Dalam penelitiannya Nindiasari mengkategorikan tahapan berpikir reflektif menjadi 1) observasi, 2) memahami masalah, 3) mengumpulkan data, 4) melakukan penilaian dari data yang dikumpulkan, 5) memilik strategi atau teknik yang paling tepat untuk pemecahan masalah, 6) konseptualisasi, dan 7) memantau solusi $^{23}$. Selain itu hasil penelitan Nindiasari juga mengungkapkan bahwa siswa dianggap telah mempunyai kemampuan berpikir reflektif apabila siswa dapat menginterpretasikan suatu permasalahan berdasarkan konsep matematika yang terlibat, mampu mengidentifikasi konsep atau rumus matematika, dapat mengevaluasi/mengecek kebenaran suatu argumen berdasarkan konsep/simbol yang digunakan, dapat menggambar analogi dua kasus serupa, dapat menganalisis dan mengklarifikasi pertanyaan dan jawaban, dapat menggeneralisasi dan menganalisis generalisasi,dapat membedakan antara data yang sangat relevan dan tidak relevan, dan dapat memecahkan masalah matematika.

Penelitian yang telah dilakukan oleh Suharna tentang profil berpikir reflektif pada siswa SD yang didasarkan pada tingkat kemampuan matematika tinggi, sedang, dan rendah, diuraikan sebagai berikut ${ }^{24}$ :

\section{TABEL 1. Profil berpikir tingkat tinggi berdasarkan tingkat kemampuan matematika}

\begin{tabular}{|c|c|c|}
\hline \multirow{2}{*}{$\begin{array}{l}\text { Langkah Berpikir } \\
\text { Reflektif }\end{array}$} & \multicolumn{2}{|c|}{ Kemampuan Matematika } \\
\hline & Sedang dan Tinggi & Rendah \\
\hline $\begin{array}{ll}\text { a. } & \text { Memahami } \\
\text { masalah }\end{array}$ & $\begin{array}{l}\text { - siswa memiliki } \\
\text { informasi/pengetahuan } \\
\text { atau data yang digunakan } \\
\text { untuk merespon, berasal } \\
\text { dari dalam diri (internal) }\end{array}$ & $\begin{array}{l}\text { - siswa dapat menentukan } \\
\text { yang diketahui dan } \\
\text { ditanyakan dalam masalah }\end{array}$ \\
\hline
\end{tabular}

19 Sabekti, A.W., et al. (2020). Validating the Reflective Thinking Questionnaire and Investigation of the Relationship Between Reflective Thinking and Academic Achievement. Companion Proceedings of the SEADRIC 2019. Pp. 138-144.

20 Daryazadeh, S., et al. (2020). A Modified tool for reflective practice in medical education: Adaptation of the Reflect Rubric in Persian. Journal of Education and Health Promotion. Vol 9 No. 24.

21 Funny, R.A., et al. (2019). Reflective Thinking Skills of Engineering Students' in Learning Statistics. Journal on Mathematics Education. Vol. 10 No. 3. pp. 445-458.

22 Ghanizadeh, A. \& Jahedizadeh, S. (2017). Validating the Persian Version of Reflective Thinking Questionnaire and Probing Iranian University Students' Reflective Thinking and Academic Achievement. International Journal of Instruction. Vol 10 No. 3. pp 209-226.

23 Nindiasari, H. (2013). Ability and Disposition Reflective Thinking Mathematically and Learning Independence High School Students through Learning with Metacognitive Approach. Doctoral Dissertation in the Graduate School of UPI. Bandung: Not published.

24 Suharna, H. (2012). Berpikir Reflektif (Reflective Thinking) Siswa SD Berkemampuan Matematika Tinggi Dalam Pemahaman Masalah Pecahan. Seminar nasional matematika dan pendidikan matematika. (pp. 377-386). 


\begin{tabular}{|c|c|c|}
\hline & $\begin{array}{l}\text { - } \quad \text { siswa bisa menjelaskan apa } \\
\text { yang telah dilakukan }\end{array}$ & $\begin{array}{l}\text { - siswa dapat menjelaskan } \\
\text { tentang pemahaman kosa } \\
\text { kata }\end{array}$ \\
\hline 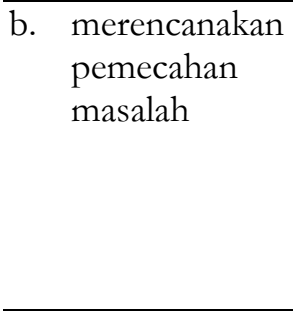 & $\begin{array}{l}\text { - } \quad \text { siswa memiliki pengetahuan } \\
\text { atau informasi yang berasal } \\
\text { dari dalam diri (internal) } \\
\text { untuk merespon } \\
\text { - } \quad \text { siswa bisa menjelaskan apa } \\
\text { yang telah dilakukan }\end{array}$ & $\begin{array}{lr}\text { - } & \text { Siswa menjelaskan, } \\
\text { menyusun, dan } & \text { data } \\
\text { mempresentasikan } & \text { pada masalah } \\
\text { - } & \text { Menjelaskan tentang } \\
& \text { bagaimana memilih operasi } \\
& \text { dalam pemecahan masalah }\end{array}$ \\
\hline $\begin{array}{l}\text { c. melaksanakan } \\
\text { rencana }\end{array}$ & $\begin{array}{ll}\text { - } & \text { siswa memiliki pengetahuan } \\
\text { atau informasi yang berasal } \\
\text { dari dalam diri (internal) } \\
\text { untuk merespon } \\
\text { - } \quad \text { siswa bisa menjelaskan apa } \\
\text { yang telah dilakukan } \\
\text { - } \quad \text { menyadari kesalahan dan } \\
\text { memperbaikinya } \\
\text { - mengkomunikasikan ide } \\
\text { dengan simbol dan gambar }\end{array}$ & $\begin{array}{l}\text { - memiliki informasi tentang } \\
\text { keterampilan perhitungan } \\
\text { walaupun jawabannya } \\
\text { belum benar } \\
\text { - siswa telah mencoba } \\
\text { mengkomunikasikan ide } \\
\text { dalam bentuk gambar dan } \\
\text { simbol } \\
\text { - siswa mampu menyadari } \\
\text { kesalahan pada saat } \\
\text { menggunakan } \\
\text { keterampilan perhitungan } \\
\text { dan memperbaikinya }\end{array}$ \\
\hline 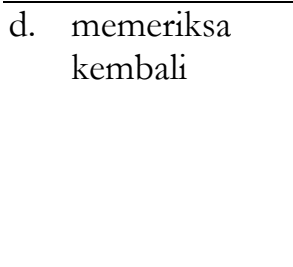 & $\begin{array}{l}\text { - } \quad \text { siswa memiliki pengetahuan } \\
\text { atau informasi yang berasal } \\
\text { dari dalam diri (internal) } \\
\text { untuk merespon } \\
\text { - } \quad \text { siswa bisa menjelaskan apa } \\
\text { yang telah dilakukan }\end{array}$ & $\begin{array}{l}\text { - siswa kesulitan dalam } \\
\text { menjelaskan apakah yang } \\
\text { diperoleh itu mendekati } \\
\text { taksiran } \\
\text { - siswa mengalami kesulitan }\end{array}$ \\
\hline
\end{tabular}

Penelitian selanjutnya oleh Salido dan Dasari, dimana mereka membagi kemampuan berpikir reflektif menjadi 3 yaitu tinggi, sedang, dan rendah. Adapun pengkriteria-annya adalah ${ }^{25}$ : (1) subjek yang memiliki kemampuan matematika tinggi, berada pada tahap refleksi dengan menunjukkan perilaku memahami pertanyaan sebelum melakukan pekerjaan, mempertimbangkan strategi penyelesaian, mampu menjelaskan langkah penyelesaian, periksa kembali jawaban, pikirkan strategi alternatif, dan wujudkan kesalahan; (2) subjek yang memiliki kemampuan matematika sedang, berada pada tahap pemahaman oleh menunjukkan perilaku, memahami pertanyaan sebelum melakukan pekerjaan, menjawab pertanyaan dengan konsep yang dikenal, mengandalkan menghafal, bisa menjelaskan proses penyelesaian, dan memeriksa jawaban hanya untuk

25 Salido, A. \& Dasari, D. (2019). The Analysis of Students' Reflective Thinking Ability Viewed by Students' Mathematical Ability at Senior High School. IOP Conf. Series: Journal of Physics: Conf. Series 1157 (2019) 022121. 
langkah penyelesaian yang tidak rumit; dan (3) subjek yang memiliki matematika rendah kemampuan, pada tahap tindakan kebiasaan dengan menunjukkan perilaku, memahami pertanyaan sebelum melakukan pekerjaan, menjawab pertanyaan sesuai dengan pengalaman rutin, tidak mampu menjelaskan langkah penyelesaian, mengabaikan pertanyaan sulit, dan tidak memeriksa ulang jawaban. Ditambahkan oleh Fatmahanik ${ }^{26}$ dalam penelitiannya tentang pola berpikir reflektif siswa kelas V SD, mengungkapkan bahwa pola berpikir siswa yang mempunyai adversity quotient pada tingkat climber berada pada tingkatan reflektif karena dalam proses berpikirnya mampu melalui fase reacting, comparing, dan contemplating.

Dari beberapa kajian tentang kemampuan berpikir reflektif serta melihat karakteristik tahap perkembangan kognitif anak, kemampuan berpikir reflektif siswa sekolah dasar kelas tinggi meliputi: pertama, keingintahuan siswa untuk mengetahui masalah yang diikuti dengan tindakan nyata siswa seperti menyebutkan apa saja yang ditanyakan dalam soal, apa saja yang diketahui, menyebutkan hubungan antara yang ditanya dengan yang diketahui, dan lain-lain. Kedua, menampilkan ide penyelesaian masalah yang dirancang sesuai pengetahuan yang telah diketahui, seperti menjelaskan jawaban pada permasalahan yang pernah didapatkan, meningkatkan masalah yang ditanyakan dengan masalah yang pernah dihadapi, dan lain-lain. Ketiga, melihat kembali penyelesaian masalah yang telah dibuat sesuai dengan urutan, kegiatan yang dilakukan pada tahap ketiga seperti menentukan maksud dari permasalahan, mendeteksi kesalahan pada penentuan jawaban, memperbaiki dan menjelaskan jika terjadi kesalahan dari jawaban, dan membuat kesimpulan dengan benar.

Dalam mengembangkan atau menggali kemampuan berpikir reflektif siswa, maka pendidik/guru perlu mengetahui proses berpikir siswa dalam memecahkan masalah matematika. Hal itu guna melacak jenis dan letak kesalahan yang dilakukan siswa dalam pemecahan masalah. Kesalahan yang dilakukan siswa dapat dijadikan sumber informasi belajar, memperbaiki pemahaman, serta membantu dalam perbaikan kualitas pembelajaran ${ }^{27}$. Menurut Fatmahanik ${ }^{28}$, berpikir reflektif dapat menjadikan proses belajar mengajar menjadi lebih bermakna, sebab siswa bukan hanya mampu memecahkan masalah tetapi siswa juga mampu mengungkapkan bagaimana proses yang berjalan dipikirannya dalam menyelesaikan permasalahan-permasalahan tersebut. Selain itu, berpikir reflektif mendorong siswa mengambil tanggung jawab untuk proses pembelajaran mereka, mengidentifikasi tujuan mereka, menilai diri mereka sendiri, dan berpartisipasi

26 Fatmahanik, U. (2018). Pola Berpikir Reflektif Ditinjau Dari Adversity Quotient. Jurnal Kodifikasia Volume 12 No.2, hal. 275-287.

27 Reskiah, Rahman, A. \& Dassa, A. (2018). Profil Berpikir Reflektif Siswa Dalam Pemecahan Masalah Aljabar Ditinjau Dari Gaya Kognitif pada Siswa Kelas VIII SMP Negeri 5 Wonomulyo Sulbar. Prosiding Seminar Nasional Vol 03, No 1. Hl. 138-146.

28 Fatmahanik, U. (2018). Pola Berpikir Reflektif Ditinjau Dari Adversity Quotient. Jurnal Kodifikasia Volume 12 No.2, hal. 275-287. 
dalam proses pembelajaran ${ }^{29}$. Salah satu cara untuk dapat melihat kemampuan berpikir reflektif adalah guru harus menyajikan suatu permasalahan yang mampu memancing siswa berpkkir reflektif tanpa melupakan sisi perkembangan psikologis dan kognitif anak. Hasil penelitian ini diharapkan dapat menjadi acuan tingkatan yang dapat dicapai oleh siswa sekolah dasar kelas tinggi dalam mengembangkan kemampuan berpikir reflektifnya.

\section{KESIMPULAN}

Pengembangan kemampuan berpikir reflektif merupakan aspek yang penting untuk diterapkan dalam rancangan proses pembelajaran matematika di sekolah dasar. Sebagai seorang pendidik, guru perlu memiliki kemampuan untuk menerapkan pengetahuan melalui pemahaman dan disposisi pribadi untuk mengoperasikan pengetahuan dan pemahaman tersebut. Siswa sekolah dasar kelas tinggi merupakan siswa pada tahap perkembangan kokret operasional dan formal operasional. Tingkat kemampuan berpikir reflektif siswa pada tahap ini meliputi kemampuan siswa menampilkan bentuk keingintahuan, menampilkan ide pemecahan masalah yang dirancang sesuai pengetahuan yang telah diketahui, dan melihat kembali penyelesaian masalah yang telah dibuat sesuai dengan urutan, memperbaiki dan menjelaskan jika terjadi kesalahan dari jawaban, dan membuat kesimpulan dengan benar. Temuan dari penelitian ini direkomendasikan untuk guru matematika dalam eksposisi pada kemampuan berpikir reflektif siswa sekolah dasar kelas tinggi dan sebagai titik referensi untuk melakukan studi masa depan dalam fokus kemampuan berpikir reflektif.

\section{DAFTAR PUSTAKA}

Ariestyan, Y., Sunardi, \& Kurniati, D. (2016). Proses Berpikir Reflektif Siswa Dalam Menyelesaikan Soal Matematika Materi Sistem Persamaan Linear Dua Variabel. Jurnal Kadikma, Vol.7,No.1, hal 94-104.

Babakr, Z. H., Mohamedamin, P., \& Kakamad, K. (2019). Piaget's Cognitive Developmental Theory: Critical Review. In: Education Quarterly Reviens, Vol 2 No.3, 517-524.

Börnert-Ringleb, M. \& Wilbert, J. (2018). The Association of Strategy Use and Concrete-Operational Thinking in Primary School. Front. Educ. 3:38. doi: 10.3389/feduc.2018.00038

Choy, S. C. \& Oo, P.S. (2012). Reflective Thinking and Teaching Practices: A

Precursor for Corporating Critical Thinking Into The Classroom. International Journal of Instruction $\mathrm{v} 5 \mathrm{n} 1 \mathrm{p} 167-182$.

29 Zafer, K.U.S. (2019). Reflective Thinking in Social Studies Curricula (Book Chapter). New Approaches in Social Studies Education (1). pp. 187-202. 
Daryazadeh, S., et al. (2020). A Modified tool for reflective practice in medical education: Adaptation of the Reflect Rubric in Persian. Journal of Education and Health Promotion. Vol 9 No. 24.

Deringöl, Y. (2019). The relationship between reflective thinking skills and academic achievement in mathematics in fourth-grade primary school students. International Online Journal of Education and Teaching (IOJET) V 6(3). 613-622.

Fatmahanik, U. (2018). Pola Berpikir Reflektif Ditinjau Dari Adversity Quotient. Jurnal Kodifikeasia Volume 12 No.2, hal. 275-287

Fuady, A. (2016). Berfikir Reflektif Dalam Pembelajaran Matematika. Jurnal Ilmiah Pendidikan Matematika Volume 1 Nomor 2. Hal. 104-112.

Funny, R.A., et al. (2019). Reflective Thinking Skills of Engineering Students' in Learning Statistics. Journal on Mathematics Education. Vol. 10 No. 3. pp. 445458.

Ghanizadeh, A. \& Jahedizadeh, S. (2017). Validating the Persian Version of Reflective Thinking Questionnaire and Probing Iranian University Students' Reflective Thinking and Academic Achievement. International Journal of Instruction. Vol 10 No. 3. pp 209-226.

Gravemeijer, K., Stephan, M., Julie, C. et al. (2017). What Mathematics Education May Prepare Students for the Society of the Future?. Int J of Sci and Math Educ. V 15, 105-123 (2017). https://doi.org/10.1007/s10763-017-9814-6.

Gurol, A. (2011). Determining The reflective thinking skills Of Preservice'Teachers in Learning and Teaching Process. Energy Education Science and Technology Part B: Social and Educational Studies, Volume (issue) 3(3): 387402.

King, L. A. (2011). The Science of Psychology: An Appreciative View. New York: McGrawHill.

Lambertus, et al. (2019). Senior High School Students. Different Cognitive Styles and Their Thinking Processes in Solving Mathematical Problems with Scaffolding. International Journal of Innovation, Creativity and Change (IJICC). Volume 10, Issue 6, 2019. Pg 163-174)

Mann, K., Gordon, J., \& Macleod, A. (2009). Reflection and Reflective Practice in Health Professions Education: A Systematic Review. Advance in Health Science Education, 14, 595-621. http://dx.doi.org/10.1007/s10459-007-9090$\underline{2}$.

Nindiasari, H. (2013). Ability and Disposition Reflective Thinking Mathematically and Learning Independence High School Students through Learning with Metacognitive 
Approach. Doctoral Dissertation in the Graduate School of UPI. Bandung: Not published.

Nuriadin, I., et al. (2015). Enhancing Of Students' Mathematical Reflective Thinking Ability Through Knowledge Sharing Learning Strategy In Senior High School. International Journal of Education and Research Vol. 3 No. 9 September 2015.

Pastorino, E.E., \& Doyle-Portillo, S. M. (2013). What is Psychology? Essentials. Belmont, USA: Wadsworth, Cengage Learning.

Prasetyowati, D. \& Kartinah. (2018). Berpikir Reflektif Mahasiswa Program Studi Pendidikan Matematika Universitas PGRI Semarang Ditinjau Dari Gaya Kognitif Field Dependent. Jurnal Silogisme: Kajian Ilmu Matematika dan Pembelajarannya Vol 3 No 2 Bulan Desember 2018 Hal 43-47.

Reskiah, Rahman, A. \& Dassa, A. (2018). Profil Berpikir Reflektif Siswa Dalam Pemecahan Masalah Aljabar Ditinjau Dari Gaya Kognitif pada Siswa Kelas VIII SMP Negeri 5 Wonomulyo Sulbar. Prosiding Seminar Nasional Vol 03, No 1. Hl. 138-146.

Sabekti, A.W., et al. (2020). Validating the Reflective Thinking Questionnaire and Investigation of the Relationship Between Reflective Thinking and Academic Achievement. Companion Proceedings of the SEADRIC 2019. Pp. 138-144.

Salido, A. \& Dasari, D. (2019). The Analysis of Students' Reflective Thinking Ability Viewed by Students' Mathematical Ability at Senior High School. IOP Conf. Series: Journal of Physics: Conf. Series 1157 (2019) 022121.

Solso, R. L. M, Otto, H., \& Kimberly, M. M. (2011). Cognitive Phsicology $8^{\text {th }}$ Edition. Allyn and Bacon.

Suharna, H. (2012). Berpikir Reflektif (Reflective Thinking) Siswa SD Berkemampuan Matematika Tinggi Dalam Pemahaman Masalah Pecahan. Seminar nasional matematika dan pendidikan matematika. (pp. 377-386).

Suharna, H. (2018). Teori Berpikir Reflektif dalam Menyelesaikan Masalah Matematika. Yogyakarta: Deepublish.

Sunbul, A.M. \& Kurnaz, A. (2016). Reflective Thinking and Teaching Reflective Thinkin. International Journal on New Trends in Education and Their ImplicationsIJONTE. Pg. 167-173

Tican, C. \& Taspinar, M. (2015). The Effects of Reflective Thinking-based Teaching Activities on Pre-service Teachers' Reflective Thinking Skills, Critical Thinking Skills, Democratic Attitudes, and Academic Achievement. The Anthropologist Journal, 20(1,2): 111-120.

Weast, D. (1996). Alternative Teaching Strategies: The Case for Critical Thinking. Teaching Sociology,24, 189-194 
144 AR-RIAYAH : Jurnal Pendidikan Dasar vol. 4, no. 2, 2020

Zafer, K.U.S. (2019). Reflective Thinking in Social Studies Curricula (Book Chapter). New Approaches in Social Studies Education (1). pp. 187-202. 